\title{
Gut Extracts of Rhynchophorus ferrugineus Larvae Olivier Affecting Bacterial Dental Caries
}

\author{
G.H. Sewify ${ }^{1}$, H.M. Hamada ${ }^{2}$, Z.A. Mustafa ${ }^{3}$ and Hani A. Alhadrami ${ }^{4,5 *}$ (D) \\ ${ }^{1}$ Deanship of Scientific Research, King Abdulaziz University, P.O. Box 80230 Jeddah 21589, Saudi Arabia. \\ ${ }^{2}$ Department of Economic Entomology and Pesticides, Faculty of Agriculture, Cairo University, Giza, Egypt. \\ ${ }^{3}$ Faculty of Dentistry, Department of Oral Diagnostic Science King Abdulaziz University, P.O. Box 80230 Jeddah \\ 21589, Saudi Arabia. \\ ${ }^{4}$ Faculty of Applied Medical Sciences, Department of Medical Laboratory Technology, King Abdulaziz University, \\ P.O. Box 80402, Jeddah 21589, Saudi Arabia. \\ ${ }^{5}$ Molecular Diagnostics Lab, King Abdulaziz University Hospital, King Abdulaziz University, P.O. Box 80402, \\ Jeddah 21589, Saudi Arabia.
}

\begin{abstract}
In vitro study was conducted to explore antibacterial properties of the larval gut extracts of Rhynchophorus ferrugineus (Red Palm Weevil) Oliver. Larval gut extracts were tested against salivary bacteria causing dental carries using the agar well diffusion method. The gut extracts significantly affected the growth of both Klebsiella spp. and Streptococcus viridans. The two bacterial species revealed significant differences in their sensitivity to the extract. The extract efficacy depended upon the concentration and time of exposure. When using $100 \%$ concentration of the extract, the mean of inhibition zones for $S$. viridans and Klebsiella spp. at $24 \mathrm{~h}$ after treatment were $1.61 \mathrm{~mm}$ and $2.50 \mathrm{~mm}$, respectively. At $48 \mathrm{~h}$ post-treatment, the mean of inhibition zones for $S$. viridans and Klebsiella spp. were $1.96 \mathrm{~mm}$ and $2.66 \mathrm{~mm}$. After 72 hours, the means zones were $2.28 \mathrm{~mm}$ and $2.91 \mathrm{~mm}$, respectively. Electron microscopic examinations showed morphological changes of the outer membrane of bacteria with a noticeable damage as a result of exposure to the gut extract. The results suggest potential use of these extracts against dental caries bacteria.
\end{abstract}

Keywords: Rhynchophorus ferrugineus, Red Palm Weevil, Antimicrobial activity, Streptococcus viridians, Klebsiella spp.

*Correspondence: hanialhadrami@kau.edu.sa; +966 505545275

(Received: November 13, 2020; accepted: March 12, 2021)

Citation: Sewify GH, Hamada HM, Mustafa ZA, Alhadrami HA. Gut Extracts of Rhynchophorus ferrugineus Larvae Olivier Affecting Bacterial Dental Caries. J Pure Appl Microbiol. 2021;15(2):613-620. doi: 10.22207/JPAM.15.2.03

C The Author(s) 2021. Open Access. This article is distributed under the terms of the Creative Commons Attribution 4.0 International License which permits unrestricted use, sharing, distribution, and reproduction in any medium, provided you give appropriate credit to the original author(s) and the source, provide a link to the Creative Commons license, and indicate if changes were made. 


\section{INTRODUCTION}

Rhynchophorus ferrugineus Olivier (Coleoptera: Curculionidae) commonly known as the red palm weevil, is a destructive insect pest to the palm trees worldwide. Previous studies demonstrated that extracts from the alimentary canal of the weevil larvae have shown potency against different species of Gram-positive and Gram-negative bacteria ${ }^{1}$. Based on those results, we decided to extend the study to evaluate the extracts' activity against bacteria present in dental carries which are considered a major reservoir for infectious agents ${ }^{2}$. Dental caries are known to harbor Streptococcus mutans and their levels in carries are indicative of the degree of contamination. This species and other streptococci species are major pathological agents of human dental caries ${ }^{3}$. It has evolved to be able to develop multiple mechanisms to colonize the teeth surfaces and has become a significant species in cariogenic biofilm ${ }^{4}$.

Dentists have prescribed antibiotics to manage and treat dental caries. However, the misuse and overuse of these drugs led to the development of bacterial resistance to antibiotics which became an increasingly challenging issue and an alarming concern around the world and has led to problems associated with using antibiotics for the treatment of endocarditis ${ }^{4-6}$. Streptococcus mutans (839 isolates) have shown particular resistance to cefuroxime, penicillin, tetracycline, and mercury in 209 human subjects ${ }^{7}$. In the light of new pathogens and diseases emerging and the increasing threats of bacteria developing resistance against antibiotics, it has become substantially very important to discover and develop new forms of antibiotics and antimicrobial drugs $^{8}$.

Insects are well known for being resistant to a wide range of pathogenic microorganisms, specially bacteria. They produce certain proteins and peptides that play a role in insect immunity against pathogens either by activating the innate immune system or by directly attacking the invading pathogen $\mathrm{s}^{9,10}$. These molecules are known as Antimicrobial peptides (AMPs). Fat bodies and the hemocytes of insects produce their AMPs and transport them to the hemolymph ${ }^{11}$. The fat body peptides secreted into the hemolymph is an effective and important mechanism, which occurs in the wounded or infected insects. Antimicrobial peptides are also secreted by the gut epithelial cells as well as those of the salivary and venom glands ${ }^{10,12}$. Throughout history, extracts from different insect organs and their secretions were used as alternative medicine to cure various diseases. Colon cancer ${ }^{13}$ and drug resistance ${ }^{14}$ are still being treated by using aqueous, alcoholic or Serratia peptidase- treated extracted from larvae of Chrysomya rufifacies (blow fly maggot) (Macquart) and Musca domestica (house fly) (Linnaeus).

Insect AMPs are intensively studied as promising and potential alternatives for conventional drugs to treat infectious diseases, cancer and to overcome bacterial resistance to antibiotics ${ }^{15-17}$. This in vitro study was conducted to evaluate inhibitory effects of the products extracted from the red palm weevil larvae against specific bacteria responsible for dental caries.

\section{MATERIALS AND METHODS Saliva Samples}

Saliva samples were collected from the adult patients who volunteered in the outpatient dental clinic, Faculty of Oral and Dental Medicine at Cairo University, Egypt, where they were treated for dental caries and periodontal diseases. The saliva samples were collected in the microbiology laboratory in the department of microbiology in Faculty of Medicine at Cairo University. The volunteer patients were selected according to standard procedures. The patients, free of any systemic and local diseases, were aged between 20-40 years. Saliva swabs for culturing were placed in tubes containing transport media to keep the bacterial swabs vital until their arrival to the laboratory. The swabs containing saliva were divided into two groups; the first group was plated on Mitis Salivarius Agar, blood, MacConkey and mannitol salt types of agar. Plates in both the groups were aerobically incubated for 24 hours at $37^{\circ} \mathrm{C}$. The second group was inoculated on selective medium and incubated for 36 hours at $35^{\circ} \mathrm{C}$ for the isolation of other bacterial species ${ }^{18}$. Isolation and Characterization of Saliva Bacteria

Saliva samples were suspended in 0.05 $M$ phosphate buffer and vortexed. This was followed by preparing 10 -fold serial dilution of the mixture to be cultured on the desired agar. 
Aliquots of $100 \mu \mathrm{l}$ were cultured on agar plates containing the base of Mitis Salivarius, which was added with a solution of $1 \%$ Potassium tellurite. In order to isolate Streptococcus sp., the above aliquot was further added with 0.2 units $/ \mathrm{ml}$ of bacitracin by raising sucrose concentration to $20 \%$ (MSB).The plates were then sealed and incubated in an anaerobic container along with a gas generating kit for $24 \mathrm{~h}$ at $37^{\circ} \mathrm{C}$. The purification of the bacterial cultures was done by continuous streaking on particular agar media, ensuing phasecontrast microscopic examination. Colonies of Streptococcus sp. appeared as dark blue, small, raised, and adherent with an irregular margin ${ }^{19}$. Colonies of morphological types of Streptococcus sp. were sub-cultured on modified Mitis Salivarius Agar base as previously described. Streptococcus $\mathrm{sp}$. was identified using pure isolates grown on a plate containing Biology Universal Growth (BUG) agar $+5 \%$ sheep blood, which was kept at $37^{\circ} \mathrm{C}$ with $6.5 \% \mathrm{CO}$. Micro-plates containing wells were then pipetted with $150 \mu$ of bacterial suspension, which were then left for 24 hours at $30^{\circ} \mathrm{C}$.

\section{Insect Sampling and Dissection}

Ismailia Governorate situated about 100

$\mathrm{km}$ east of Cairo was selected as the collection site for the larvae of Red Palm Weevil; large sized larvae (7-10 ${ }^{\text {th }}$ larval instars) were collected from infested palms. In the laboratory, the larvae were topically sterilized with $70 \%$ ethanol, left to dry, immobilized on ice, and dissected under a stereoscopic microscope in cold distilled water using sterile tools. About $20 \mathrm{~g}$ of gut tissues (content excluded), were collected separately and homogenized using a manual glass grinder. The supernatant, collected after centrifuging the homogenates at $10,000 \times \mathrm{g}$ for 15 minutes at $4^{\circ} \mathrm{C}$, was stored in the sterilized Eppendorf tubes at $-80^{\circ} \mathrm{C}$ for further use $\mathrm{e}^{20-22}$.

\section{Evaluation of Antibacterial Effects}

The minimum inhibitory concentration (MIC) is considered a basic measure of the activity of any antimicrobial agent and its ability to inhibit the growth of the tested pathogen ${ }^{23}$. The antimicrobial activity was evaluated by measuring clear zones of growth inhibition using the agar well diffusion method ${ }^{24}$.

TEM Examination

The effect of the gut extracts on Streptococcus viridans was observed using
Transmission Electron Microscopy (TEM). Cells of S. viridans were scraped off the culture, exposed to gut extract, and incubated at $37^{\circ} \mathrm{C}$ for 24 hours. Cells were fixed with $5 \%$ formaldehyde cacodylate buffer and 3\% glutaraldehyde. The treated and untreated cells were washed several times before fixing them in $1 \%(\mathrm{w} / \mathrm{v})$ osmium tetroxide in cacodylate buffer. The cells were examined with a Zeiss transmission electron microscope (EM 910) after counterstaining them with $1 \%$ lead citrate and $0.5 \%$ uranyl acetate.

\section{Statistical Analysis}

A randomized design was applied to analyze the data. Assitat software ${ }^{25}$ was used to compare treatments by using the Least Significant Difference Test (LSD) ${ }^{26}$. The effect of gut extracts and changes occurring on the inhibition zones were analyzed by using ANOVA test. The relationship between the time of exposure and growth inhibition was also determined.

Table 1. Antimicrobial activity of gut extracts from larvae of the red palm weevil $R$. ferrugineus against S. viridans and Klebsiella spp. according to the well diffusion method

\begin{tabular}{|c|c|c|c|c|}
\hline \multirow[t]{2}{*}{ Days } & \multirow[t]{2}{*}{ Conc. } & \multicolumn{2}{|c|}{ Inhibition Zones (mm.) } & \multirow[t]{2}{*}{ Mean } \\
\hline & & $\begin{array}{c}\text { Streptococcus } \\
\text { viridians }\end{array}$ & $\begin{array}{l}\text { Klebsiella } \\
\text { spp }\end{array}$ & \\
\hline \multirow[t]{5}{*}{1} & $10 \%$ & 1.68 & 2.58 & 2.13 \\
\hline & $25 \%$ & 1.56 & 2.40 & 1.98 \\
\hline & $50 \%$ & 1.54 & 2.38 & 1.96 \\
\hline & $100 \%$ & 1.65 & 2.65 & 2.15 \\
\hline & Mean & 1.61 & 2.50 & $2.05^{c}$ \\
\hline \multirow[t]{5}{*}{2} & $10 \%$ & 2.00 & 2.69 & 2.34 \\
\hline & $25 \%$ & 1.90 & 2.59 & 2.24 \\
\hline & $50 \%$ & 1.83 & 2.50 & 2.16 \\
\hline & $100 \%$ & 2.11 & 2.88 & 2.49 \\
\hline & Mean & 1.96 & 2.66 & $2.31^{b}$ \\
\hline \multirow[t]{10}{*}{3} & $10 \%$ & 2.09 & 2.75 & 2.42 \\
\hline & $25 \%$ & 2.00 & 2.64 & 2.32 \\
\hline & $50 \%$ & 1.93 & 2.59 & 2.26 \\
\hline & $100 \%$ & 2.28 & 2.91 & 2.59 \\
\hline & Mean & 2.07 & 2.72 & $2.40^{\mathrm{a}}$ \\
\hline & $10 \%$ & 1.92 & 2.67 & $2.30^{\mathrm{b}}$ \\
\hline & $25 \%$ & 1.82 & 2.54 & $2.18^{\mathrm{c}}$ \\
\hline & $50 \%$ & 1.76 & 2.49 & $2.13^{d}$ \\
\hline & $100 \%$ & 2.01 & 2.81 & $2.41^{a}$ \\
\hline & Mean & $1.88^{\mathrm{b}}$ & $2.63^{a}$ & \\
\hline
\end{tabular}

LSD value at 0.05 : 


\section{RESULTS}

\section{Antimicrobial Activity}

The bacterial species $S$. viridans and Klebsiella spp. were isolated from patients' saliva samples. The treatment with Red Palm Weevil extracts showed antimicrobial activity and affected the growth of both types of the isolated bacteria. Table 1 shows the inhibitory effects of the extracts against both bacterial species. The Multivariable analysis (ANOVA) of the data showed significant differences in the effectiveness of these extracts against the studied bacteria. The inhibition zone area for both bacterial species i.e., S. viridans and
Klebsiella spp., increased proportionately with exposure time up to 72 hours.

Results presented in Table 1 show that the bacterial growth inhibition caused by gut extract treatments was concentration and time dependent. At all concentrations of the tested extracts, $S$. viridans was significantly much less affected than Klebsiella spp. When using high concentration (100\%), the mean of inhibition zones for S. viridans and Klebsiella spp. at $24 \mathrm{~h}$ after treatment were $1.61 \mathrm{~mm}$ and $2.50 \mathrm{~mm}$, respectively. At $48 \mathrm{~h}$ post-treatment, the mean of inhibition zones for $S$. viridans and Klebsiella

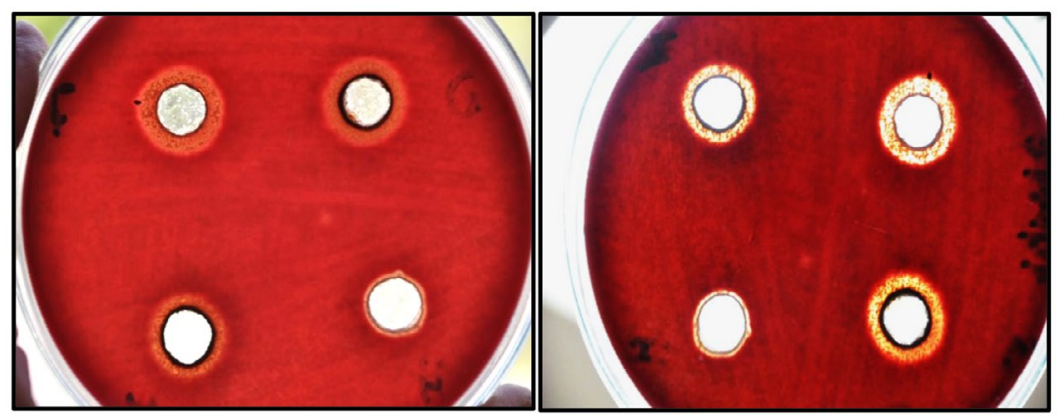

Fig. 1. Zone of inhibition of $S$. viridans caused by gut extracts from red palm weevil larvae at 1 day after treatment.

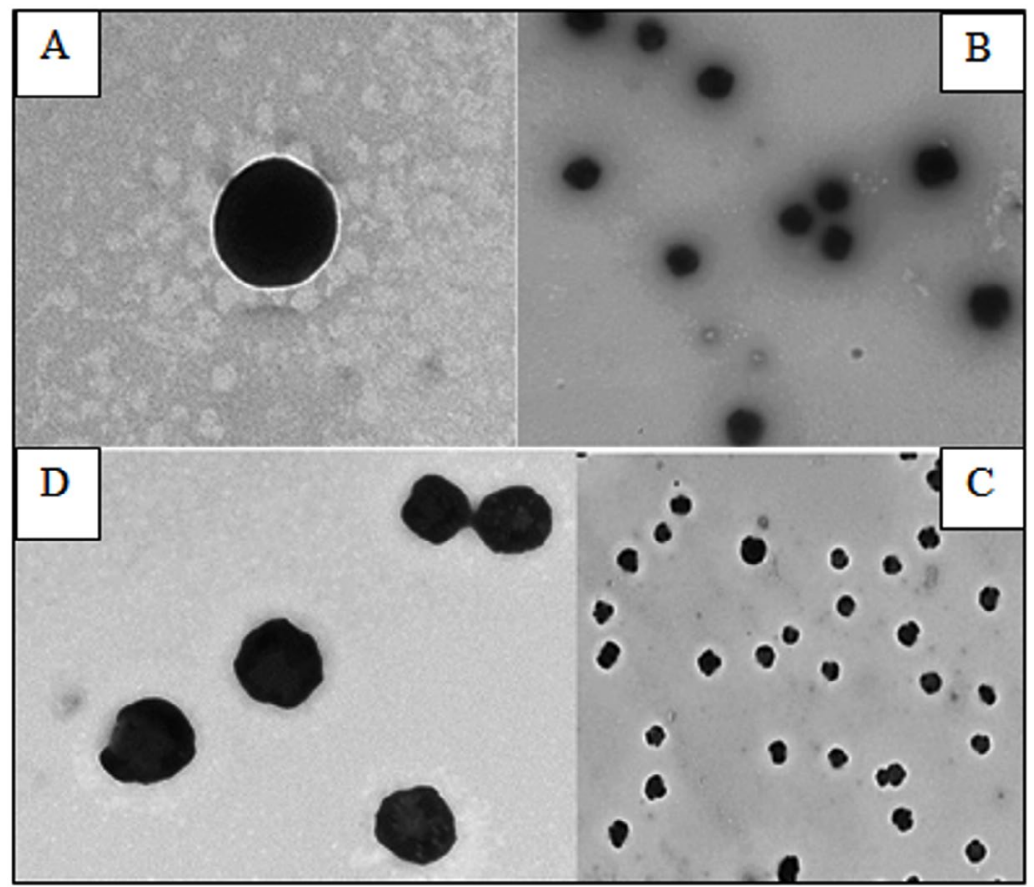

Fig. 2. TEM photo showing the effect of gut extracts from the larvae of red palm weevil on $S$. viridans $24 \mathrm{~h}$ after treatment. Untreated bacteria at (A) $168000 x$ and (B) 41400x magnification; treated bacteria at (C) $36600 x$ and (D) 36600x magnification. 
spp. were $1.96 \mathrm{~mm}$ and $2.66 \mathrm{~mm}$. After 72 hours, the means zones were $2.28 \mathrm{~mm}$ and $2.91 \mathrm{~mm}$, respectively. The statistical analysis showed significant differences between the effect of different concentrations of weevil gut extract on both S. viridans and Klebsiella spp. . These results are illustrated in Fig. 1.

There was a significant difference between the two bacterial species when treated with different concentrations of the gut extract. The highest concentration caused a significant growth inhibition zone compared with the lowest concentration. The statistical analysis showed significant differences in inhibition zones as a result of the duration of exposure.
The TEM examination showed that the untreated cells had normal cell shapes and undamaged structures (Fig. $2 \mathrm{~A}$ and B). However, morphological changes (Fig. $2 \mathrm{C}$ and D), and malformation of the cell membrane of the bacterial cells and damages due to gut extract exposure were observed $24 \mathrm{~h}$ after treatment (Fig. $3)$. There was also separation between the cell membrane and the cytoplasm of S. viridans (Fig.S 3c-f) associated with cell hydrolyses (Fig. 3f).

\section{DISCUSSION}

A mixture of Streptococci and a number of species of the Viridans group can be found in the oral cavity, including $S$. mitis, S. mutans, $S$.
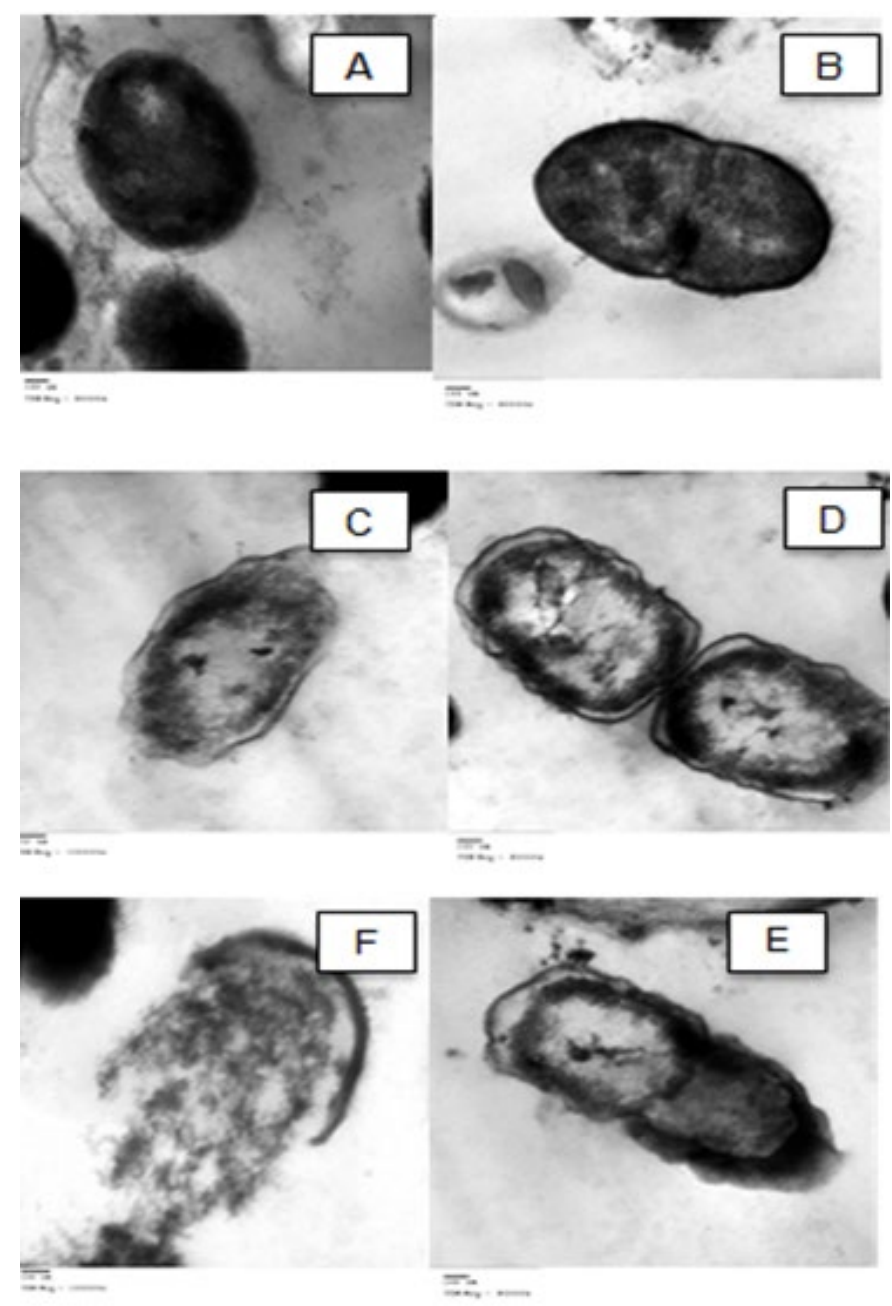

Fig. 3. TEM photo showing malformation in the shape and cell hydrolysis of $S$. viridans $24 \mathrm{~h}$ after treatment with the alimentary canal extracts of red palm weevil larvae. (A and B) untreated cells, (C, D, E) malformation, (F) hydrolyzed cell. 
milleri, S. sanguis, and S. salivarius ${ }^{27}$. S. viridans is considered an important micro-organism that can cause infections leading to dental caries and heart valve damage ${ }^{27}$. The ability of $S$. viridans to cause carious lesions is well documented. However, effective treatment with antibiotics is faced with the emergence of new resistant bacteria ${ }^{28}$. In the present study, the effect of the gut extract of the red palm weevil $R$. ferrugineus Olivier was tested against $S$. viridans (gram positive) and Klebsiella spp. (gram negative). The agar well diffusion method clearly demonstrated that the gut extract had antimicrobial activity in vitro and caused zone of growth inhibition for both bacterial species. The effectiveness of the extract depended on the concentrations applied and duration for which the bacteria were exposed.

The electron microscopy examination of treated $S$. viridans cells showed the presence of malformation of the cell membrane and leakage of the intracellular constituents due to cell hydrolysis. These results are supported by previous studies which indicated that antibiotics have antibacterial activity that caused membrane disruption for different bacterial strains $\mathrm{s}^{29-31}$. The sensitivity of $S$. viridans to the gut extract can be attributed to the fact that Gram positive bacteria are only surrounded by a peptidoglycan cell membrane and lack the presence of the outer cell membrane which makes it vulnerable to the effect of antimicrobial peptides of the gut extract. This peptidoglycan layer is relatively porous and allows the AMP molecules to pass through and penetrate the cell ${ }^{1}$. On the other hand, gram negative bacteria have an additional membrane known as the outer membrane. This outer membrane works as a barrier that plays an important role as a protective mechanism against antimicrobial agents and antibiotic selection pressure thus promoting bacterial antibiotic resistance ${ }^{32}$. Interestingly in this study, the gram negative bacteria Klebsiella spp. were more sensitive and had significantly larger zones of inhibition compared to the gram positive bacteria $S$. viridans after being treated with the gut extract. This result is similar to the findings reported after treating both $E$. coli (gram negative bacteria) and $S$. aureus (gram positive bacteria) with the external secretions of the red palm weevi ${ }^{33}$. Similar results were also reported when studying the antimicrobial effects of $T$. molitor secretions on different microbes including gram positive and gram negative bacteria ${ }^{34}$. The effect of the gut extract on gram negative bacteria might be attributed to the presence of other factors or components in addition to the antimicrobial peptides that can interact together to enhance and strengthen their immunosuppressive efficacy. Further studies are needed to explore and isolate these components responsible for the inhibition effect.

In summary, developing countries face major challenges in developing and maintaining health care, for which they need novel, effective, and affordable procedures, treatments and medications to treat various infections. The gut extract from larvae of the red palm weevil $R$. ferrugineus have the potential to serve as a natural antibacterial agent to control and prevent the growth of different pathogenic micro-organisms including dental carries bacteria.

\section{CONCLUSION}

This study presents an effective treatment for dental carries bacteria using crude gut extract of $R$. ferrugenius. These extracts showed potential antimicrobial activity against S. viridans and Klebsiella spp., which may be further explored and evaluated as a potential alternative to conventional antibiotics.

\section{ACKNOWLEDGMENTS}

The authors acknowledge the financial support provided by King Abdulaziz University's Deanship of Scientific Research (DSR). The authors are thankful to Prof. Steve Harakeh special infectious agents unit, King Fahd Medical research Center for manuscript revision.

\section{CONFLICT OF INTEREST}

conflict of interest.

The authors declare that there is no

\section{AUTHORS' CONTRIBUTION}

GS and HAA wrote the manuscript, collect data and statistical analysis. HMH and ZAM did the experimental work.

\section{FUNDING}

This study was supported by 
grants no.G:113-305-1439.from the Deanship of Scientific Research (DSR), King Abdulaziz University, Jeddah, Saudi Arabia.

\section{DATA AVAILABILITY}

All datasets generated or analyzed during this study are included in the manuscript

\section{ETHICS STATEMENT}

Not applicable.

\section{REFERENCES}

1. Sewify GH, Hamada HM, Alhadrami HA. In Vitro Evaluation of Antimicrobial Activity of Alimentary Canal Extracts from the Red Palm Weevil, Rhynchophorus ferrugineus Olivier Larvae. BioMed Res Int. 2017;2017:8564601. doi: 10.1155/2017/8564601

2. Okada T, Takada K, Fujita K, et al. Differentiation of banding patterns between Streptococcus mutans and Streptococcus sobrinus isolates in rep-PCR using ERIC primer. J Oral Microbiol. 2011;3:7190. doi: 10.3402/ jom.v3i0.7190

3. Loesche, W. J. Role of Streptococcus mutans in human dental decay. Microbiol Rev. 1986; 50: 353-80.

4. Jubair $\mathrm{HH}$. The relationship between biofilm forming and antibiotics resistance of Streptococcus mutans isolated from dental caries. Int J Curr Microbiol App Sci. 2015;4(5):568-574.

5. William B, Rwenyonyi CM, Swedberg G, Kironde F. Cotrimoxazole Prophylaxis Specifically Selects for Cotrimoxazole Resistance in Streptococcus mutans and Streptococcus sobrinus with Varied Polymorphisms in the Target Genes folA and folP. Int J Microbiol. 2012;2012:916129. doi: 10.1155/2012/916129

6. Tsuda H, Yamashita Y, Shibata Y, Nakano $Y$, Koga T. Genes Involved in Bacitracin Resistance in Streptococcus mutans. Antimicrob Agents Chemother. 2002;46(12):3756-3764. doi: 10.1128/ AAC.46.12.3756-3764.2002

7. Leistevuo J, Jarvinen $H$, Osterblad $M$, Leistevuo $T$, Huovinen P, Tenovuo J. Resistance to Mercury and Antimicrobial Agents in Streptococcus mutans Isolates from Human Subjects in Relation to Exposure to Dental Amalgam Fillings. Antimicrob Agents Chemother. 2000;44(2):456-457. doi: 10.1128/AAC.44.2.456457.2000

8. Manniello MD, Moretta A, Salvia R, et al. Insect antimicrobial peptides: potential weapons to counteract the antibiotic resistance. Cell Mol Life Sci. 2021. doi: 10.1007/s00018-021-03784-z

9. Wu Q, Patocka J, Kuca K. Insect Antimicrobial Peptides, a Mini Review. Toxins. 2018;10(11):461. doi: 10.3390/ toxins10110461

10. Ganz T. The role of antimicrobial peptides in innate immunity. Integrative and Comparative Biology. 2003;43(2):300-304. doi: 10.1093/icb/43.2.300

11. Yi H-Y, Chowdhury $M$, Huang $Y-D, Y u X-Q$. Insect antimicrobial peptides and their applications. Appl Microbiol Biotechnol. 2014;98(13):5807-5822. doi: 10.1007/s00253-014-5792-6

12. Mylonakis E, Podsiadlowski L, Muhammed M, Vilcinskas A. Diversity, evolution and medical applications of insect antimicrobial peptides. Philos Trans $R$ Soc $B$ : Biol Sci. 2016;371(1695):20150290. doi: 10.1098/ rstb.2015.0290

13. Hou L, Shi Y, Zhai P, Le G. Antibacterial activity and in vitro antitumor activity of the extract of the larvae of the housefly (Musca domestica). J Ethnopharmacol. 2007;111(2):227-231. doi: 10.1016/j.jep.2006.11.015

14. Park SO, Shin JH, Choi WK, Par BS, Ohi JS, Jung A. Antibacterial activity of housefly maggot extracts against MRSA (Methicillin- resistant Staphylococcus aureus) and VRE (Vancomycin- resistant enterococli). J Envron Biol. 2010;31(5):865- 871.

15. Ratcliffe NA, Mello CB, Garcia ES, Butt TM, Azambuja P. Insect natural products and processes: New treatments for human disease. Insect Biochem Mol Biol. 2014;41(10):747-769. doi: 10.1016/j. ibmb.2011.05.007

16. Roy S, Saha S, Pal P. Insect natural products as potential source for alternative medicines - A Review. World Scientific News. 2015;19;69-83.

17. Brady D, Grapputo A, Romoli O, Sandrelli F. Insect cecropins, antimicrobial peptides with potential therapeutic applications. Int J Mol Sci. 2019;20(23):5862. doi: 10.3390/ijms20235862

18. Wong SH, Cullimore DR, Bruce DL. Selective medium for the isolation and enumeration of Klebsiella spp. Appl Environ Microbiol. 1985;49(4):1022-1024. doi: 10.1128/AEM.49.4.1022-1024.1985

19. Nikawa H, Makihira S, Fukushima H, et al. Lactobacillus reuteri in bovine milk fermented decreases the oral carriage of mutans streptococci. Int J Food Microbiol. 2004;95(2):219-223. doi: 10.1016/j. ijfoodmicro.2004.03.006

20. Valzano M, Achille G, Burzacca F, et al. Deciphering microbiota associated to Rhynchophorus ferrugineus in Italian samples: a preliminary study. Journal of Entomological and Acarological Research. 2012;44(3):e16. doi: 10.4081/jear.2012.e16

21. Oren Z, Shai Y. Mode of action of linear amphipathic helical antimicrobial peptides. Biopolymers. 1998; 47:451-63.

22. Cudic M, Otvos LJr. Intracellular targets of antibacterial peptides. Curr Drug Targets. 2002;3(2):101-106. doi: 10.2174/1389450024605445

23. Andrews JM. Determination of minimum inhibitory concentrations. J Antimicrob Chemother. 2001;48(Suppl 1):5-16. doi: 10.1093/jac/48.suppl_1.5

24. Turillazzi S, Perito B, Pazzagli L, Pantera B, Gorfer $S$, Tancred M. Antibacterial activity of larval saliva of the European paper wasp Polistes dominulus (Hymenoptera,Vespidae). Insect Soc. 2004;51:339-341. doi: 10.1007/s00040-004-0751-3

25. Silva FAS. The ASSISTAT software: statistical assistance, in Proceedings of the International Conference on Computers in Agriculture, pp. 249-298, American Society of Agriculture Engineers, 6 Cancun, Mexico, 1996.

26. Snedecor GW, Cochran WG. Statistical Method. Published by The lowa State University Press. 1980. 
27. Y. Refoua, A Study of Streptococcus viridans in the maxillofacial region. Journal of Dentistry of Tehran Uni. of Med. Sci. 2005; 2(4):174-179.

28. WHO. High levels of antibiotic resistance found worldwide, new data. Shows. http://www.who.int/ mediacentre/news/releases. 2018.

29. Yanping W, Bai J, Zhong K, et al. Antibacterial activity and membrane-disruptive mechanism of 3-p-trans-coumaroyl-2-hydroxyquinic Acid, a novel phenolic compound from pine needles of Cedrus deodara, against Staphylococcus aureus. Molecules. 2016;21(8):1084. doi: 10.3390/molecules21081084

30. Hartmann M, Berditsch M, Hawecker J, Ardakani MF, Gerthsen D, Ulrich AS. Damage of the bacterial cell envelope by antimicrobial peptides gramicidin $S$ and PGLa as revealed by transmission and scanning electronmicroscopy. Antimicrob Agents Chemother. 2010;54(8):3132-3142. doi: 10.1128/AAC.00124-10
31. KarikalanS, Mohankumar A. Antibiogram of streptococcus mutans isolated from dental caries patients. International Journal of Medical and Health Research. 2016;2(3): 79-83, 2016.

32. Blair JM, Webber MA, Baylay AJ, Ogbolu DO, Piddock LJV. Molecular mechanisms of antibiotic resistance. Nat Rev Microbiol. 2015;13(1):42-51. doi: 10.1038/ nrmicro3380

33. Pu YC, Xiang HJ, Liang $X Y$, et al. External immune inhibitory efficiency of external secretions and their metabolic profiling in Red Palm Weevil, Rhynchophorus ferrugineus (Coleoptera: Curculionidae). Frontiers in Physiology. 2020;10(1624). doi: 10.3389/ fphys.2019.01624

34. Qiang CK, Yang ZF, Du YZ. Study on the antimicrobial activity of the defensive secretion of Tenebrio molitor L. Biotechnology. 2006a(16):22-24. 